\title{
Hubungan Dukungan Sosial dengan Tingkat Stres pada Warga Binaan Pemasyarakatan Perempuan di Lembaga Pemasyarakatan
}

\author{
${ }^{1}$ Akhmad Yanuar Fahmi Pamungkas \\ ${ }^{1}$ STIKES Banyuwangi, Banyuwangi, Indonesia \\ yanuarfahmi20@gmail.com
}

\begin{abstract}
Introduction: Social support is expected to reduce stress on inmates. Previous study stated that social support has no relationship with the level of stress on female prisoners while other study mentioned that social support has a significant effect on reducing stress levels on inmates. Based on these phenomena, the researchers were interested in examining the relationship of social support with stress levels in female prisoners, to find out implicitly the relationship between social support with stress levels.

Method: This study used a cross-sectional technique. The number of samples was 59 female inmates in a prison in West Java with purposive sampling technique. Data collection in this study used survey employing the DASS questionnaire sheet and Social Provisions Scale. The statistical test used to process data is the Rank Spearman SPSS 22 test for windows 7. This research has been conducted by the Ethics Institute of Stikes Banyuwangi.

Results: The results of the study found that most of the fostered residents received less social support as many as 34 respondents and 25 respondents experienced mild stress levels. The result of statistical calculation of Spearmen Rank obtained correlation co-efficient value of 0.665 and sig. $(2$-tailed $)=0.000(<0.05)$, thus it means that there is a significant relationship between social support and the level of stress in female inmates.

Conclusion: Female inmates who receive good social support will have a positive impact on their psychological i.e. not experiencing stress. Conversely, the less they get social support, the more they experience distress.
\end{abstract}

Keywords: Prison, Social Support, Stress Level

\begin{abstract}
Abstrak
Pendahuluan: Dukungan sosial diharapkan dapat mengurangi stres pada warga binaan pemasyarakatan (WBP). Penelitian sebelumnya menyebutkan bahwa dukungan sosial tidak mempunyai hubungan terhadap tingkat stres pada WBP perempuan. Namun, dalam penelitian lain disebutkan bahwa dukungan sosial berpengaruh signifikan terhadap penurunan tingkat stres pada WBP(Windistiar, 2016). Melihat fenomena tersebut peneliti tertarik meneliti hubungan dukungan sosial dengan tingkat stres pada WBP perempuan untuk mengetahui hubungan antara dukungan sosial dengan tingkat stres.

Metode: Jenis penelitian menggunakan teknik cross-sectional. Jumlah sampel 59 WBP perempuan di sebuah Lembaga pemasyarakatan di Jawa Timur dengan teknik purposive sampling. Pengumpulan data dengan metode survei menggunakan lembar kuesioner DASS
\end{abstract}


dan Social Provisions Scale. Uji statistik yang digunakan untuk mengolah data yaitu uji Rank Spearman SPSS 22 for windows 7. Penelitian ini telah dilakukan uji etik oleh lembaga etik Stikes Banyuwangi.

Hasil: Hasil penelitian didapatkan sebagian besar WBP mendapatkan dukungan sosial yang kurang sejumlah 34 responden dan 25 responden mengalami tingkat stres ringan. Hasil perhitungan statistik Rank Spearman didapatkan hasil nilai correlation co-eficient - 0,665 dan sig. $(2$-tailed $)=0,000(<0,05)$ yang artinya ada hubungan yang signifikan antara dukungan sosial dengan tingkat stres pada warga binaan wanita.

Kesimpulan: WBP yang mendapatkan dukungan sosial yang baik maka akan berdampak positif pada psikologis warga binaan yaitu tidak mengalami stres. Sebaliknya apabila warga binaan mendapatkan dukungan sosial yang kurang maka akan menyebabkan warga binaan mengalami stres.

Kata kunci: Dukungan Sosial, Lapas, Stres, Warga Binaan Pemasyarakatan Perempuan

\section{PENDAHULUAN}

Stres merupakan suatu keadaan dimna individu mengalami suatu tekanan terhadap suatu masalah yang harus diatasi untuk mendapatkan suatu hasil yang maksimal (Bartsch \& Evelyn, 2015). Stres dapat terjadi kepada siapa saja, salah satunya adalah pada warga binaan yang ada di Lembaga Pemasyarakatan (Wilson, 2004 dalam Lubis et al., 2014)

Data International Centre for Prison Studies (2015) menunjukkan bahwa total populasi warga binaan pemasyarakatan (WBP) di dunia berjumlah sembilan juta jiwa. Indonesia menduduki peringkat sembilan terkait jumlah WBP. Direktorat Jenderal Pemasyarakatan Kementerian Hukum \& HAM (2015) melaporkan pada tanggal 22 Februari 2015 terdapat 137.495 WBP menyebar secara menyeluruh di Indonesia dan pada tahun 2018 mengalami peningkatan mencapai 242.903 WBP. Hasil Riset Kesehatan Dasar (Riskesdas) tahun 2013 menunjukkan bahwa prevalensi gangguan emosional atau stres di Indonesia adalah sebesar 6,0\% atau sekitar 37,728 orang (Kementerian Kesehatan Republik Indonesia, 2013). Berdasarkan studi pendahuluan yang dilakukan di suatu
Lembaga Pemasyarakatan di Jawa Timur pada tanggal 16 Januari 2019 dengan menggunakan kuesioner diambil dari 15 orang didapatkan data WBP perempuan yang mengalami stres ringan sebanyak sebelas orang, stres sedang sebanyak tiga orang, dan seorang mengalami stres berat.

Penanganan stres sangat tergantung pada koping seseorang. Sebagian besar WBP perempuan memiliki koping yang cukup baik dan kurang baik (Laili, Andriany, Anggorowati, \& Salam (2018), semakin rendah koping seseorang maka semakin tinggi peluang seseorang tersebut terkena stress (Demir, Demir, Bulut, \& Hitsar, 2014). Koping WBP juga dipengaruhi oleh dukungan sosial.

Dukungan sosial yang diberikan oleh sekitar merupakan salah satu cara untuk menanggulangi stres WBP di Lapas disebabkan sebuah dukungan sosial dapat mengurangi perilaku negatif melalui hubungan interpersonal yang dijalin antara WBP (Nur \& Shanti, 2011). Dukungan sosial bersumber dari hubungan baik yang dijalin oleha lingkungan sekitar dan individu merasa nyaman secara fisik dan psikologis yaitu dalam bentuk 
mendukungan secara emosional seperti dapat mendengarkan curhatan dan menunjukkan perbuatan mampu untuk percaya terhadap apa yang dikatakan, support perilaku seperti memberikan apa yang dibutuhkan (Balogun, Jacobs, Jarzabkowski, Mantere, \& Vaara, 2014).

Soewaryo (2007) menyebutkan bahwa dukungan sosial tidak mempunyai hubungan terhadap tingkat stress pada WBP perempuan dikarenakan waktu pemberian jam kunjung keluarga yang sedikit sehingga tidak mampu memberikan secara maksimal. Penelitian lain menyebutkan bahwa dukungan sosial berpengaruh signifikan terhadap penurunan tingkat stres pada WBP disebabkan karena dukungan sosial dapat meringankan beban fisik maupun spiritual WBP (Windistiar, 2016). Melihat fenomena tersebut peneliti tertarik meneliti hubungan dukungan sosial dengan tingkat stres pada warga binaan wanita, untuk mengetahui hubungan antara dukungan sosial dengan tingkat stress.

\section{METODE}

Jenis penelitian yang digunakan adalah korelasi. Dalam penelitian ini peneliti menggunakan rancangan penelitian crosssectional. Penelitian ini menggunakan jumlah populasi 69 WBP perempuan dengan jumlah sampel 59 WBP perempuan dan 10 orang tidak dilibatkan karena tidak mengikuti pengambilan data.

Pengumpulan data dengan metode survei menggunakan lembar kuesioner DASS dan Social Provisions Scale. Analisis data menggunakan uji korelasi hubungan dukungan sosial dengan tingkat stres dengan uji rank Spearman dibantu fasilitas SPSS 22 for Windows 7. Penelitian ini telah lolos uji etik oleh lembaga etik STIKES Banyuwangi dengan nomor surat etik 079-KEPK.

\section{HASIL}

Table 1. Distribusi Frekuensi Dukungan Sosial WBP Perempuan di Lembaga Pemasyarakatan

\begin{tabular}{lcc}
\hline \multicolumn{1}{c}{ Variabel } & f & \% \\
\hline Dukungan Sosial & & \\
Cukup & 25 & 42 \\
Kurang & 34 & 58 \\
& & \\
Tingkat Stres & & \\
Normal & 15 & 26 \\
Ringan & 25 & 42 \\
Sedang & 12 & 20 \\
Berat & 5 & 9 \\
Sangat Berat & 3 & 2 \\
\hline
\end{tabular}

Tabel 1 menjelaskan bahwa sebagian besar WBP perempuan di Lapas mendapatkan dukungan sosial yang kurang yaitu sejumlah 58\%. Hasil uji Rank Spearman diperoleh nilai Correlation Coefficient -0,665 dan Sig. (2-tailed) = $0,000(<0,05)$ maka Ha diterima yang artinya yang berarti ada hubungan yang signifikan antara dukungan sosial dengan tingkat stres. Penelitian ini menunjukkan bahwa apabila dukungan sosial semakin besar maka semakin rendah tingkat stres dan demikian sebaliknya. Nilai korelasi Rank Spearman adalah -0,665 (0,60 0,799) yang berarti bahwa terdapat hubungan yang signifikan antara dukungan sosial dengan tingkat stres pada WBP perempuan kuat

\section{PEMBAHASAN}

Hubungan dari penelitian ini menggambarkan bahwa semakin besar dukungan sosial yang diberikan maka semakin rendah tingkat stres dan sebaliknya semakin rendah dukungan sosial maka semakin tinggi tingkat stres pada warga binaan wanita. 
Hasil penelitian ini sesuai dengan penelitian Suliastri (2013) yang mengatakan bahwa ada hubungan yang signifikan antara dukungan sosial dengan tingkat stres. Terry, Rawle, dan Callan (2005) Dukungan Sosial dapat mencegah tingkat stres selama menjalani masa tahanan.

Fakta di atas menunjukkan dukungan sosial kurang yang dialami oleh WBP perempuan di Lapas berdampak pada psikologis WBP yaitu mengalami stres. Berdasarkan penelitian yang telah dilakukan sejumlah $58 \%$ responden, yang memiliki dukungan sosial kurang dapat juga mengalami stres sangat berat, berat, sedang, ringan dan normal dikarenakan keluarga tidak berkunjung, jarang berkomunukasi dengan teman di Lapas, pegawai kurang memperhatikan kondisi WBP, dukungan sosial kurang dapat mengakibatkan banyak WBP mengalami stres ringan karena mengalami beban psikologis yang luar biasa.

Hasil penelitian menunjukkan bahwa responden yang mendapatkan dukungan sosial yang kurang dan mengalami tingkat stres ringan $(14,75 \%)$, sedang $(20 \%)$, berat (9\%) dan sangat berat (3\%). WBP yang mendapatkan dukungan sosial yang cukup dan mengalami tingkat stres ringan (delapan responden), tingkat stres sedang (dua responden).

Dirgayunita (2016) menjelaskan diperlukan upaya untuk membantu WBP mengubah pikiran-pikiran atau pernyataan diri negatif dan kenyakinan-keyakinan yang tidak rasional dan mengganti cara berpikir dari yang tidak logis menjadi logis. Upaya tersebut yaitu memberikan bimbingan, selama kehilangnya (dibatasi) kemerdekaan bergeraknya para warga binaan tidak boleh diasingkan dari masyarakat dan pekerjaan yang diberikan kepada WB tidak boleh sekedar pengisi waktu.
Dampak dari keterlambatan dalam penanganan tersebut bisa berpengaruh besar pada proses perawatan dan pengobatan serta penyembuhan pada warga binaan. Dukungan sosial yang diberikan oleh keluarga, teman dan lingkungan sekitar kepada warga binaan akan memberikan kekuatan luar biasa warga binaan akan merasa diperhatikan dan dibutuhkan. Kondisi ini akan mampu mempengaruhi psikologis warga binaan menjadi lebih tenang dalam menghadapi permasalahan yang dihadapi. Ketenangan inilah yang pada akhirnya mampu menekan terjadinya stres menjadi stres sangat berat atau bahkan menjadi tidak mengalami stres. Selain memanfaatkan dukungan sosial, ada beberapa intervensi yang dapat menurunkan dari tingkat stres, kecemasan yaitu dengan mindfulness, ruqyah syar'iyah, dan peer support group (Arifuddin \& Yanuar, 2018; Yanuar, Dwidiyanti, \& Wijayanti 2018; Wiguna, 2018).

\section{KESIMPULAN DAN SARAN}

Kesimpulan dari penelitian ini adalah sebagian besar WBP mendapatkan dukungan sosial yang kurang, sebagian kecil WBP mengalami tingkat stres ringan. Penelitian selanjutnya disarankan untuk memberikan solusi dan intervensi dari permasalahan yang dihadapi oleh WBP wanita.

\section{DAFTAR PUSTAKA}

Arifuddin, Y. W., \& Fahmi, A. Y. (2018). The effect of ruqyah syar'iyyah therapy on anxiety, stress and depression among health science students. Holistic Nursing and Health Science, 1(2), 68-76. 
Bartsch, K., \& Evelyn (2015). The wounded healer (Terjemahan). Semarang: Panji Graha.

Balogun, J., Jacobs, C., Jarzabkowski, P., Mantere, S. \& Vaara, E. (2014), Placing strategy discourse in context: Sociomateriality, sensemaking, and power. Journal of Psychology. 51(2), 175-201. doi: 10.1111/joms.12059

Demir, S., Demir, S. G., Bulut, H., \& Hisar, F. (2014). Effect of mentoring program on ways of coping with stress and locus of control for nursing students. Asian Nursing Research, 8(4), 254-260. doi: 10.1016/j.anr.2014.10.004

Direktorat Jenderal Pemasyarakatan Kementerian Hukum \& HAM. (2015). Status pelaporan jumlah penghuni per UPT pada Kanwil. Diperoleh dari http://smslap.ditjenpas.go.id

Dirgayunita, A. (2016). Depresi: ciri, penyebab dan penanganannya. Journal An-Nafs, $\quad 1(1), \quad$ doi: $10.33367 / \mathrm{psi} / \mathrm{v} 1 \mathrm{i} 1.235$

International Centre for Prison Studies. (2015). Highest to lowest - Prison population total. Diperoleh dari http://www.prisonstudies.org/highesttolowest/prison-population-total

Kementerian Kesehatan Republik Indonesia. (2013). Riset kesehatan dasar 2013. http://.go.id/downloads/rinkesda s201 3/ hasil\%20 rinkesds\%2020 13pdf.

Laili, N., Andriany, M., Anggorowati, \& Salam, A. Y., (2018). Coping of prerelease women's prisoners. Jurnal Ners dan Kebidanan Indonesia, 6(2), 85-90. doi: 10.21927/jnki.2018.6(2).1-6

Lubis, et al. (2014). Hak asasi manusia dan pembangunan. Jakarta: Yayasan Lembaga Bantuan Hukum Indonesia.

Nur, A. L. \& Shanti, L. P. (2011). Kesepian pada narapidana LP. Kedungpane Semarang ditinjau dari dukungan sosial keluarga dan status perkawinan. (Skripsi, UNISSULA).

Sulastri. (2013). Hubungan dukungan sosial dengan tingkat stres anak pidana di Lapas Anak Pria Tangerang. (Skripsi, Universitas Indonesia). Diperoleh dari http://lontar.ui.ac.id.

Soewaryo, Y. N. (2007). Hubungan dukungan sosial dengan tingkat stres pada narapidana di Rumah Tahanan Situbondo. Diperoleh dari http://eprints.umm.ac.id/12857/1/Hub ungan_Dukungan_Sosial_Dengan_Ti ngkat_Strespada_Narapidana_Di_Ru mah_Tahanan_Situbondo.Pdf

Terry, D. J., Rawle, R., \& Callan, V. J. (2005). The effects of social support on adjustment to stress: The mediating role of coping. Personal Relationships, 2(2), 97-124. doi: 0.1111/j.1475-6811.1995.tb00080.x

Wiguna, R. I., Dwidiyanti, M., \& Sari, S. P. (2018). The Influence of Mindfulness on the Decreasing Anxiety in Nursing Students to Support Academic Learning: A Literature Review. Holistic Nursing and Health Science; Volume 1, Nomor 1 : (Juli 2018). Retrieved from https://ejournal2.undip.ac.id/index.ph p/hnhs/article/view/2916. 
Windistiar, D. E. (2016). Hubungan dukungan sosial dengan stres narapidana wanita. (Skripsi, Universitas Muhammadiyah Malang). Diperoleh dari http://eprints.umm.ac.id/34404/1/jiptu mmpp-gdl-devintaele-44142-1skripsi-a.pdf

Yanuar, A., Dwidiyanti, M., \& Wijayanti, D. Y. (2018). Effectiveness of Mindfulness on Decreasing stress in health professional students: A systematic review. Holistic Nursing and Health Science, 1(1), 1-11. 